\title{
Payroll-exempt labor incomes increase inequality at the top
}

In recent decades, the inequality of household income has increased globally. A common trend is increased income inequality at the top of the distribution. The sources of this trend are a matter of debate. Increased demand for analytical and managerial skills is said to have strongly increased labor incomes at the top. Other scholars have indicated that structural conditions, such as financialization or favorable taxation, have benefited top-earning households. Here, we contribute to the latter line of reasoning. We show that payroll taxes exempt parts of high labor incomes, reinforcing income inequality at the top. Such taxation has large fiscal volume and redistributive power. However, our knowledge about the distributional consequences of payroll taxation as a tax scheme is remarkably thin. Many countries, such as Germany and the US, restrict payroll taxes to a maximum amount, resulting in significant payroll tax-exempted incomes for high-earning households. Strongly growing top-labor incomes thus lead to increased payroll taxexempted incomes for households at the upper parts of the distribution and, consequently, to higher income inequality. We use Germany (1992-2017), a highly redistributive country, as a case study. Our empirical results suggest that: a) households increasingly profit from payroll-exempted labor incomes across the upper quarter; b) this benefit has increased over time; and c) increased amounts of payroll tax-exempted labor income explain up to $60 \%$ of income dispersion at the top of the distribution. We discuss the generalizability of our case study for other countries, especially the US.

\section{Introduction}

Since the 1970s, many countries have experienced rising economic inequality (Nolan, Richiardi, and Valenzuela 2019). A common trend across countries is increased income concentration within the top of the distribution (McCall and Percheski 2010; Lakner and Milanovic 2016). The sources of this trend are a matter of debate. Some scholars claim that firms increasingly reward rare talents (Kaplan and Rauh 2013) and that analytical tasks have profited from technological shifts in recent decades (Liu and Grusky 2013). Other voices suggest that structural changes, such as financialization and outsourcing, have played a more important role compared to increased market prices for talents and skills (Stainback, Tomaskovic-Devey, and Skaggs 2010).

Within the latter stream, scholars have pointed out that taxation rules matter strongly for our understanding of inequality (Martin, Mehrotra, and Prasad 2009; Martin and Prasad 2014). As this work shows, taxes, overall, reduce income inequality (Wimer et al. 2020; Bloch, Pisu, and Joumard 2013). However, if we leave the bird's eye view of overall inequality and zoom into parts of the income distribution, research within this stream has clearly shown that taxes may 
increase inequality within parts of the distribution. Income tax cuts implemented in recent decades across many rich countries have increased the incomes of the highest-income households, as compared to middle-income households (Duncan and Peter 2016; Volscho and Kelly 2012). This is also the case for reductions in corporate taxes (Bawa and $\mathrm{Vu} 2020$ ) and property taxes (Scheve and Stasavage 2016). A country's income tax system can also reinforce gender-specific and racial inequalities across the income distribution (O'Brien 2017; McCaffery 2007). Furthermore, some tax systems favor family types, such as the breadwinner model with children, relative to others, thereby increasing income inequality between families (Schechtl 2021).

We can therefore conclude that growing inequality, especially within the top, is at least partially based on a weakened relationship between taxes paid and increased top incomes. The repeated finding within the literature is that households at the top of the distribution both have higher incomes and pay more taxes in absolute value over time. However, incomes have grown more strongly than increases in tax due. Such findings have led to concerns that the redistributive role of fiscal policies in rich countries is declining (Goodhart and Pradhan 2020; Immervoll and Richardson 2011). Current tax systems, these voices claim, do not serve as the strong brake on inequality that they did some decades ago. Their power to contain inequality at the top has diminished strongly since the 1980 s.

Here, we claim that we still need to include payroll taxation as the second and typically largest pillar of a country's tax system when explaining inequality trends. ${ }^{1}$ Governments charge both payroll and income taxes on labor income. Thus, we need to include both as structural factors in our explanations of income inequality. However, while previous research agrees on the importance of income taxes for increased inequality, payroll taxation plays no role in current debates about its causes (Angeles and Kemmerling 2020; Gornick and Smeeding 2018; Wang, Caminada, and Goudswaard 2014). ${ }^{2}$ Within this article, we make the case that we need to include a country's payroll tax system as an important structural factor for income inequality, too.

We believe it is essential to study the role of payroll taxation for inequality for at least two reasons. First, the country-specific rules of payroll taxation may result in more favorable pre-

\footnotetext{
${ }^{1}$ We use the terms "payroll taxation" and "social security contributions" interchangeably.

2 This may be the case because payroll taxes are a means of financing social security spending, which reduces inequality overall (Marx, Salanauskaite, and Verbist 2016; Brady and Bostic 2015). However, the influence of payroll taxation needs to be distinguished from that of public transfers.
} 
tax to post-tax income transitions for high-income earners. For example, countries such as the US, Germany, Finland, Italy, and the Netherlands charge such contributions up to a maximum amount: the social security contribution thresholds. ${ }^{3}$ If the earned income exceeds the maximum threshold, employees pay no further payroll tax on the earned income above the threshold. The higher the earned income is above the maximum threshold, the smaller the difference between the income before and after all taxes. So far, we do not know for any of the above-mentioned countries how large this assumed income benefit for households is. Furthermore, we do not know whether top-earning households profit more compared to high- or medium-earning ones (and if so, by how much), and how this information may help us explain income inequality.

Second, the rules of payroll taxation differ greatly between countries, which may explain different inequality trends to a large extent. Countries differ in terms of which kinds of social security fall under mandatory payroll taxation. Switzerland does not include health insurance in payroll taxes, but Germany, Finland, and the US do. Other countries have maximum amounts for only parts of payroll taxes. In contrast to German health insurance, US health insurance (Medicare) has no maximum contribution threshold. However, the US Old Age, Survivors and Disability Insurance (OASDI) scheme has a maximum contribution threshold. Therefore, specific rules on payroll taxation linked to the dispersion of labor income could be of great importance in understanding different patterns or trends in income inequality between countries. In order to understand such cross-country differences, we need a solid understanding of how and why payroll taxation affects the distribution of incomes given a country's payroll tax system. As yet, we lack any such knowledge.

Our article is a first step toward including payroll taxes in explanations of inequality. We analyze for the case of Germany, a high-redistribution country, a) how payroll tax rules affect household incomes across the distribution, b) whether their effect increases over time, and c) whether understanding these helps us explain the increased household income dispersion seen within the top of the income distribution since 1992.

Our aim here is not to criticize a particular payroll tax system for increasing inequality. Payroll taxation per se has certainly not caused higher household income inequality. We stress that growing labor incomes are the most likely culprit for large parts of that increase. However, we hypothesize that the increase in household income inequality may have been much smaller without large increases in payroll tax-exempted labor income. Thus, we consider the payroll

\footnotetext{
${ }^{3}$ The Organisation for Economic Co-operation and Development (OECD) lists comparative differences in payroll taxation, including maximum thresholds: https://stats.oecd.org/Index.aspx?DataSetCode=TABLE_III2
} 
tax system to have reinforced income inequality within the upper parts of the distribution, even though this was not an intended outcome.

We focus on the upper quarter of the distribution because wages above the contribution thresholds are most likely earned by households in this area of a country's income distribution. Using data from the Socio-Economic Panel Study (SOEP V35), we estimate Quantile Treatment Effect (QTE) models to account for the benefits of payroll taxation rules at the household level (Powell 2020) and decompositions of Unconditional Quantile Regressions (UQR) for distributional consequences of such household-level effects (Fortin, Lemieux, and Firpo 2011). Our analysis exemplifies why both of these consequences of payroll taxation need to be distinguished from each other (Borgen, Haupt, and Wiborg 2020).

Our results for one of the most redistributive countries in the world show a steeply growing benefit of payroll-exempted labor income within the upper quarter, a benefit which has increased sharply in recent decades. The increased amount of payroll-exempted labor income explains up to $60 \%$ of the income dispersion within the upper quarter of the household income distribution for the period between 1992 and 2017. Thus, we cannot view the German payroll tax system as a redistributive channel alone. Rather, it reinforces inequality at the top.

After setting out our results for Germany, we discuss the relevance of payroll taxation for explanations of income inequality for other countries, especially for the US.

\section{Payroll tax-exempted labor income and income inequality}

\subsection{Labor incomes and income inequality at the top}

Countries around the world have experienced growing income dispersion within upper parts of the household income distribution over recent decades (OECD 2011; Blundell et al. 2018). Increased earnings are the main source of higher household income wealth (Godechot 2016; Bach, Corneo, and Steiner 2013). In this regard, capital income is also important, but only the super-rich have seen exceptional capital returns over the past few decades (Bartels and Jenderny 2015; Piketty, Saez, and Zucman 2018). Increased capital income alone cannot explain the increased income dispersion in the upper range of the household income distribution, which includes far more households than the super-rich alone. With this in mind, Piketty and Saez $(2003,1)$ have argued that "the working rich have replaced the rentiers at the top of the income distribution". The salaries of top managers, lawyers, and doctors have skyrocketed since the 1980s, especially in the US. Piketty and Saez (2003) document a large shift within the highest 
ranges of the US income distribution from entrepreneurs to high-earners, which also represents a shift away from the importance of capital to a greater importance of very high labor incomes.

Germany is no exception to this pattern. The upper deciles of the household income distribution have increased much faster than the middle and lower ones over recent decades (Grabka and Goebel 2020). Labor incomes are the major source of this polarization (Biewen, Ungerer, and Löffler 2019).

It is thus of utmost interest to study how governments have responded to the increased importance of labor incomes in growing income inequality. Payroll taxation could be one way to counter this trend.

\subsection{Payroll taxation in Germany}

Payroll taxes serve a government's budgetary needs to finance public transfers, such as pensions, sick leave, unemployment pay, and elderly care. Payroll taxes are typically viewed as an insurance payment against life-course risks, such as disability, involuntary unemployment, or the inability to care for oneself as an elderly person. Countries differ in terms of which of these insurances are mandatory and which they define as private spending. They also vary in how much of their transfer spending is based on payroll taxes, resulting in varying payroll tax rates. For example, Germany finances public pensions from a mix of payroll and income tax revenues (Meier and Werding 2010).

Since 1995, Germany has charged payroll taxes to cover four public transfers: pensions, unemployment pay, sick pay, and pay for elderly care. ${ }^{4}$ Payroll taxes in Germany are due on individual labor incomes, with two factors determining their amount. Contribution rates constitute the percentage of the employee's wage that must be paid to social security. This rate is essentially a flat tax on the pre-tax labor income. In 2018, it amounted to $21.6 \%$ for pensions and unemployment insurance, and $18.15 \%$ for health and nursing care insurance, representing an overall payroll tax of $39.75 \%$ on labor incomes.

However, contributions have a ceiling, with predefined income contribution thresholds. Labor earnings above this threshold are not subject to payroll taxes. For Germany, there are two separate contribution thresholds: the first sets contribution limits for the health and nursing care insurance; the second does so for pensions and unemployment insurance. The second threshold is significantly higher than the first and also differs between East and West Germany. In 2018,

\footnotetext{
${ }^{4}$ Germany introduced payroll taxes for elderly care in 1995 . The other three pillars date back to the original Bismarckian foundation of the social security system.
} 
the threshold for pensions and unemployment insurance in West Germany was $€ 78,000$ for annual labor income, while it was $€ 69,600$ in East Germany. The much lower threshold for health and nursing care insurance was $€ 53,100$ for both parts of the country.

Any amount of earned income above the contribution threshold is exempt from the obligation to contribute to social insurance. If, for instance, a West German employee earned $€ 100,000$ in 2018, she would pay $18.15 \%$ payroll taxes for health and nursing care insurance on her first $€ 53,100$. The remaining $€ 46,900$ would be exempt from health and nursing care insurance contributions. In addition, she would pay $21.6 \%$ payroll taxes on the first $€ 78,000$. The remaining $€ 22,000$ would be exempt from all payroll taxes. In total, she would pay €26,485.65 in payroll taxes, $26.5 \%$ of her total labor income. Therefore, her relative payroll tax due would be substantially lower than the $39.75 \%$ payroll tax rate paid by employees earning labor incomes below the contribution thresholds. The larger the amount of labor income above the contribution thresholds, the more favorable the pre-tax to post-tax difference.

Both parts of the German payroll tax system are constantly changing. First, the German government raised contribution rates significantly during the 1990s, partly as a result of budget problems due to the reunification process. A large number of East German pensioners and unemployed workers became part of the social security system literally overnight. The total payroll tax rate went up from $35.6 \%$ in 1990 to $42.1 \%$ in 1997 . Since then, the overall rate has been declining; it fell to $39.75 \%$ in 2018 - mostly due to lower unemployment insurance contributions.

Second, German governments have increased contribution thresholds steadily, mostly to offset the effect of inflation. Typically, governments base changes in contribution thresholds on the average wage change. However, they can deviate from this approach if it is deemed necessary. On average, the thresholds for health and care insurances have grown by about $€ 665$ per year. In West Germany, the threshold for pension and nursing care has risen by $€ 1,265$ per year. Thus, both thresholds have grown further apart over time. Additionally, the government increased the pension and nursing care contribution threshold from $€ 54,000$ in 2002 to $€ 61,200$ in 2003, the largest increase in a single threshold since reunification.

\subsection{Labor income inequality, payroll taxation, and household incomes}

\subsubsection{How payroll taxes disperse incomes across the distribution}

Both income and payroll taxes transform pre-tax incomes to the post-tax income level. Two distinctions in the way they function are noteworthy. First, payroll taxes are due only on labor 
incomes, whereas income taxes are due on all the income sources of the tax unit. Second, payroll taxes are charged prior to income taxes. Both these aspects have important implications for explanations of income inequality.

First, the benefits of payroll-exempted income appear only for households with substantial labor incomes. Households with substantial pensions and capital incomes alone cannot profit in this way. As individual labor incomes typically increase across the distribution of disposable household incomes, they are very likely to show increasing amounts of labor incomes above the contribution thresholds. This should lead to a decreasing ratio of wage taxes paid to labor income earned across the distribution.

Second, the typical labor income composition within a household is important for understanding this payroll tax effect. If we compare two-parent families with a total labor income of $€ 100,000$ in 2018, in Germany, it matters very much whether a single earner brings home all the labor income or both parents contribute equally. In the first case, the family will have a large payroll tax advantage because most labor income is above both contribution thresholds. In the second case, there is no payroll tax advantage at all because both labor incomes of $€ 50,000$ are below the lower contribution threshold. Any combination of incomes between the two cases will result in different degrees of payroll tax advantage.

Third, payroll-exempted labor income is still subject to regular income taxation. Thus, the higher the labor income, the higher the amount of payroll-exempted income, but the higher also the household's income tax rate due to the strong progressive nature of the German income tax system. Payroll tax benefits do not translate mechanically into post-tax income gains. They are not tax-free gains but are part of the household's income tax due, which alters the household's income advantage in terms of payroll-exempted labor incomes.

Consequently, there are important relations between payroll taxation and income taxation for our understanding of inequality. As for many other countries, the German income tax system amplifies income differences between single- and equal-earning families (Schechtl 2021). It allows married couples to split their income after the deduction of payroll taxes and to calculate the income tax on both parts separately (Bach et al. 2011). In the case of a single breadwinner household, this means that half of the single high income - including potential payroll tax advantages - is transferred to the spouse. In most cases, this reduces income taxes considerably because progressive income taxation results in substantially higher income tax rates for upper incomes. If the top earner has a larger share of labor income above the contribution thresholds, 
the final household income tax will be reduced further because of this splitting rule. The larger the difference between incomes within the couple, the more beneficial the splitting rule for the household and the higher the post-tax household income.

We can thus conclude that the absolute income gain for households increases across upper parts of the distribution, because larger sums of individual labor income are exempted from payroll tax, even if they are subject to income taxation. However, expectations about relative advantages are not as straightforward. Relative advantage requires payroll tax benefits to increase even more strongly than incomes on the way to the top of the entire distribution. For example, a payroll tax advantage of $€ 3,500$, or $5 \%$ for a household with a disposable income of $€ 70,000$, requires this advantage to be even higher than $€ 4,500$ for a household with an income of $€ 90,000$. An increasing relative advantage across the distribution would thus refer to a steeper growth of payroll tax benefits in relation to household income. Nevertheless, we do expect to find relative advantages for households with labor incomes above both contribution thresholds. In this case, we assume that the amount of payroll-exempted labor incomes grows steeply across the upper quarter, even resulting in growing relative income advantages due to payroll taxation (H1a).

For households with labor incomes above the lower threshold, the relative advantage might be even larger for those at the beginning of the upper quarter compared to those at the top. These households have at least one high earner, but not a top earner with a labor income above both thresholds. Compared to households without high-earners, having a labor income above only the lower threshold is definitely a relative advantage. Looking further up at even higher ranks of the distribution, households with at least one earner above the lower threshold compete with households with high-earners and much larger amounts of payroll tax-exempted labor income. These more potent competitors reduce this particular type of advantage considerably, and even generate a relative disadvantage at the top where more is required than labor incomes above the lower threshold alone to make it into these ranks. We thus expect that relative benefits for household labor incomes above the lower threshold will decrease across the upper quarter (H1b).

\subsubsection{Increased labor income inequality and increased amounts of payroll-exempted incomes}

As in many other countries, labor income inequality in Germany has increased in recent decades, with upper incomes increasing much more steeply than middle ones (Dustmann, Ludsteck, and Schönberg 2009). As top-labor incomes have grown more strongly than 
contribution thresholds, a higher share of earnings have become exempt from paying payroll taxes over time. In this situation, a payroll tax system with contribution thresholds, such as the German one, creates an increasing relative advantage for households with high labor incomes. Contribution thresholds turn payroll taxation from a flat tax into a regressive tax at the top. This regressiveness at the top increases over time if top-labor incomes increase more steeply than contribution thresholds. In Germany, contribution thresholds have increased constantly across the observation period, but governments have based their increases mostly on changes in average earnings. We thus expect that households benefit increasingly over time from having an earner above the contribution thresholds (H2).

\subsubsection{The relevance of payroll-exempted labor incomes for growing income inequality}

If our arguments hold and labor incomes disperse more strongly over time, this should have resulted in accumulations of payroll tax-exempted labor income across the upper parts of the distribution. Consequently, we should be able to attribute substantial parts of increased household income dispersion to this accumulation process $(\mathrm{H} 3 \mathrm{a})$.

Governments can counter this accumulation by increasing contribution thresholds more strongly than average earnings. However, as discussed above, the German government has done so only once since reunification, between 2002 and 2003. This has had two consequences. First, extraordinary increases reduce the share of households with payroll tax-exempted labor income. The households falling below the increased thresholds will thus pay more payroll taxes than before and have reduced household incomes. Second, all households at the top pay more payroll taxes because a larger amount of their labor incomes falls under mandatory payroll taxation. Thus, the substantial increase of contribution thresholds alone should have reduced income inequality over time (H3b).

\section{Data, variables, and methods}

\subsection{Data}

We use waves 1993-2018 of the German Socio-Economic Panel (SOEP V35) (Goebel et al. 2019). The SOEP is an annual representative panel of German households with several subsamples. For our purposes, we use the data as repeated cross-sections. ${ }^{5}$ Our measures refer to the previous year but not the survey year. Thus, our observation span is 1992 to 2017.

\footnotetext{
${ }^{5}$ Previous research on inequality in Germany compared the results of the SOEP as a repeated cross-section with data based on different sampling and reported negligible differences (Dustmann, Fitzenberger, and Zimmermann 2018). A reasonable concern here is that unobserved, time-invariant heterogeneity among households correlated
} 
The SOEP does not allow for detailed multivariate analyses of the very top of the income distribution. Combining the SOEP and the German Taxpayer-Panel, Bach, Corneo, and Steiner (2013) find that even though all households in the SOEP high-income sample are located in the top $20 \%$ of the much more precise German Taxpayer-Panel, only a few of the SOEP households are located within the top percentile of the merged data.

Our aim, however, is not to make statements about super-rich households, but to analyze processes that have dispersed the upper quarter of the income distribution, leading to higher income richness on aggregate. We caution that, within the top of the distribution, households might display special unobserved characteristics, such as large business assets or incomes in family offices, which might influence our analysis to some extent (Albers, Bartels, and Schularick 2020). We thus report results up to the $96^{\text {th }}$ percentile, which serves as our lower bound of the assumed influence of payroll tax-free labor income shares at the top.

We use list-wise deletion for missing cases and cross-sectional household weights for descriptive and multivariate results. Our analytic sample consists of 277,742 households over 26 years, which we pool in 13 time points to increase power. The standard errors of the models account for this household clustering. Our syntax files are publicly available at the author's GitHub account.

\subsection{Variables}

Our dependent variable is the logged post-tax equivalent household income deflated to 2014 levels (Wagner, Frick, and Schupp 2007). We use the Organisation for Economic Co-operation and Development (OECD) equivalence scale, which weighs the household head at 1 and adds a 0.5 weight for each additional household member older than 14 years and 0.3 for all members under 14.

We measure all characteristics at the household level. We define binary explanatory variables for whether at least one member of the household earns labor income above the contribution threshold for a) health care and nursing care insurance, and b) pension and unemployment insurance. We refer to the first as the lower threshold and to the second as the upper threshold.

Our models compare households with the same amount of labor, capital, and pension income as we control for the household's income components. We let these households differ with

with predictors could bias results. We estimated unconditional quantile models with household fixed effects to assess this point (see Appendix B3). The results do not significantly differ and thus do not change our conclusions. 
respect to whether at least one member earns above one or two contribution thresholds. Our rationale here is to compare households with the same amount of pre-tax income in terms of their post-tax income. If our claim that payroll taxation matters for post-tax income is correct, then we should observe differences in disposable incomes between households with the same pre-tax income but with different tax due.

As indicated, the mix of income contributions to the household income is of the utmost importance for the payroll tax effect. We thus need to control for characteristics explaining these income contribution differences. We also need to control for types of income that are not subject to contribution thresholds, such as those for civil servants, and need to take into account the fact that West and East Germany have different contribution thresholds. ${ }^{6}$

Thus, we control for the characteristic of whether any household member is a civil servant or self-employed. If a household has a civil servant, we do not count this household as one with earnings above the contribution thresholds because German civil servants typically do not pay payroll taxes. The SOEP simulation of payroll tax data assumes that the self-employed do not necessarily pay social security contributions as a payroll tax. Thus, they set all social security contributions to zero. This is, however, a very strong assumption. First, the public insurance system is attractive even for the self-employed. Second, most self-employed professionals (such as physicians, midwives, and dentists) have a mandatory insurance scheme. Third, Germany introduced mandatory health insurance for the self-employed in 2009. We therefore impute social security contributions for the self-employed as if they were employees. Robustness checks for a sample without imputed social security contributions for the self-employed do not alter our conclusions.

We control for the household's labor force status, which we classify into eight categories based mainly on the annual working hours of the household's members. First, we define pensioner households as households in which a pensioner is the breadwinner, contributing at least half of the total household income out of their labor and pension. If income from pensions and wages (if pensioners continue to work to some extent) makes up more than half of total income, the household is considered a pensioner household. All other households are categorized depending on the labor market integration of the working-age household members. For this, every individual's working hours are set in relation to the maximum full-year, full-time working hours

\footnotetext{
${ }^{6}$ Because we control for the household's amount of labor, capital, and pension incomes, we do not need to include further covariates explaining their variation. In order to show this empirically, we estimated models including industry composition and the occupation of the main earner as further controls (Appendix, Figures B2a and $\mathrm{B} 2 \mathrm{~b})$. The results do not differ.
} 
(2,080 hours). SOEP information on annual working hours is constructed using information on employment status in the survey year, the average number of hours worked per week, and the number of months worked in the previous year (reported in the activity calendar). This continuous variable for individuals therefore ranges from 0 to 1 ; it is added up for all individuals of working age in the household and then divided by the number of working-age persons in the household. Our resulting variable on household labor market integration therefore again ranges from 0 to 1. Zero-earner households have close to zero labor market integration (a maximum of 0.1). We classify households with only one person of working age as either single working full-time (at least 0.95 ) or single working part-time (between 0.45 and 0.95 ). Households with low work intensity (either singles or couples) have values between 0.1 and 0.45 , so that their sum of annual working hours amounts to less than half a single full-time equivalent. Doubleearner households have close to full employment (at least 0.95). Single breadwinner households have values between 0.45 and 0.55 , and those with a top-up earner between 0.55 and 0.95 .

Furthermore, the household's educational composition is defined using three education groups, based on the International Standard Classification of Education: no professional qualification (ISCED 1-2); completed vocational training (ISCED 3-5); and completed higher education (ISCED 6). These categories further distinguish between single and couple households. Couple households in which one partner has no qualification while the other has a vocational or academic degree are combined into one category because of sample size. Thus, there are eight categories: no qualification (single); vocational training (single); academic (single); both without qualification; couple with only one qualification; both with vocational training; vocational/higher education; and both with higher education.

Further, we take into account whether the household is childless, whether it is situated in East or West Germany, whether it is a young household (according to the age of the household head), and whether the household head has a migration background. Table 1 gives an overview of the variables used and shows descriptive statistics for several time points. 
Table 1: Average values for the outcome, treatment, and control/proneness variables. Households are the smallest unit of analysis. The data were weighted with cross-sectional household weights.

\begin{tabular}{|c|c|c|c|c|}
\hline & & 1993 & 2003 & 2013 \\
\hline Outcome & Log. equ. disp household income & 9.87 & 9.91 & 9.91 \\
\hline \multirow[t]{3}{*}{ Treatments } & At least one member earns above & & & \\
\hline & a) the lower threshold & 0.15 & 0.15 & 0.14 \\
\hline & b) the upper threshold & 0.07 & 0.05 & 0.06 \\
\hline \multirow{28}{*}{ 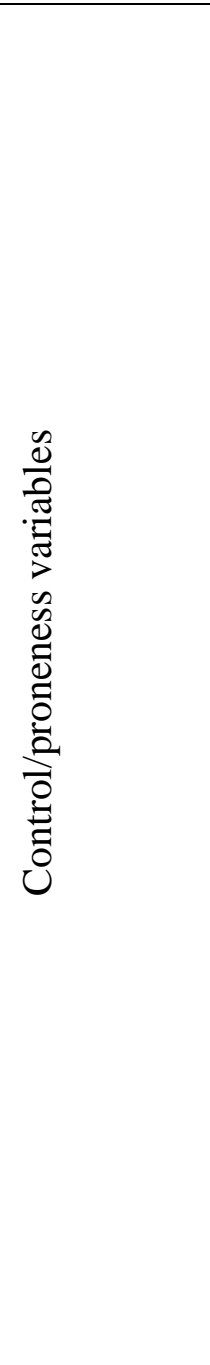 } & Household capital income & 2394 & 3412 & 3429 \\
\hline & Household labor income & 19517 & 20133 & 19388 \\
\hline & Household pension income & 6039 & 6686 & 7312 \\
\hline & Single, low education & 0.12 & 0.08 & 0.08 \\
\hline & Single, medium education & 0.27 & 0.32 & 0.35 \\
\hline & Single, high education & 0.05 & 0.08 & 0.12 \\
\hline & Couple, low/low education & 0.03 & 0.02 & 0.02 \\
\hline & Couple, medium/low education & 0.12 & 0.08 & 0.06 \\
\hline & Couple, medium/medium education & 0.27 & 0.28 & 0.22 \\
\hline & Couple, high/medium education & 0.09 & 0.09 & 0.10 \\
\hline & Couple, high/high education & 0.04 & 0.04 & 0.05 \\
\hline & Pensioner household & 0.36 & 0.37 & 0.40 \\
\hline & Zero-earner household & 0.04 & 0.05 & 0.06 \\
\hline & Double-earner household & 0.12 & 0.09 & 0.09 \\
\hline & Single breadwinner household & 0.14 & 0.11 & 0.06 \\
\hline & Top-up earner & 0.12 & 0.12 & 0.11 \\
\hline & Both in part-time work & 0.01 & 0.01 & 0.01 \\
\hline & Precarious work & 0.03 & 0.03 & 0.03 \\
\hline & Single full-time work & 0.15 & 0.17 & 0.18 \\
\hline & Single part-time work & 0.03 & 0.06 & 0.06 \\
\hline & Household with civil servant & 0.07 & 0.05 & 0.05 \\
\hline & Household with self-employed & 0.07 & 0.07 & 0.07 \\
\hline & Young household & 0.14 & 0.08 & 0.07 \\
\hline & Female-headed household & 0.33 & 0.33 & 0.36 \\
\hline & Households with immigration status & 0.05 & 0.07 & 0.09 \\
\hline & East Germany & 0.18 & 0.17 & 0.17 \\
\hline & Household with no children & 0.74 & 0.76 & 0.81 \\
\hline & Observations & 5905 & 10548 & 13497 \\
\hline
\end{tabular}

\subsection{Methods}

We have argued that we need to capture the consequences of payroll tax-exempted labor incomes for inequality at two different levels. At the household level, exempted income constitutes an advantage with respect to the pre-tax to post-tax income transmission. This aspect refers to between-household inequality based on a benefit due to taxation. We also expect that the relative advantage increases over time, because top-labor incomes increase more strongly than contribution thresholds. On a distributional level, we hypothesize that this advantage 
reinforces household income inequality at the top. Here, we also expect an increased influence across the distribution and over time.

To quantify differences across the distribution for each level of analysis, we model the household-level consequence using QTE, and model the influence on the unconditional distribution using decompositions of UQR (for a discussion of this difference, see Borgen, Haupt, and Wiborg 2020).

\subsubsection{QTE models}

In a first step, we assess whether the benefit of labor incomes that are above the contribution thresholds increases within the upper quarter of the distribution and whether it changes over time. We estimate unconditional QTE models (Powell 2020). The QTE model first estimates an expected household income distribution given a set of variables and then calculates the quantile value differences between the observed and the expected distribution conditional on treatment variables. The treatment variable measures whether the household has at least one member earning above a certain contribution threshold. All other covariates serve as proneness variables helping us make inferences about the potential household income distribution (see Table 1). ${ }^{7}$

The coefficients of this QTE model allow us to infer the difference that we would expect in household incomes between two households with given characteristics in the same quantile of the outcome distribution that differ in terms of the treatment characteristic. Using such a model, we can quantify how much the household income of a household with a member who earns above the contribution thresholds differs from a household without such a member, accounting for the fact that both households have the same set of observed household characteristics, such as the total labor income or capital income, or the same household composition. Thus, without the influence of the contribution thresholds, we assume that both households are equally prone to having a household income with a specific quantile value.

We use a treatment variable for each of the thresholds to infer the consequences of earning a labor income only above the lower threshold or above both thresholds. If a household has at least one member who earns a labor income above both thresholds, the coefficient for the upper

\footnotetext{
${ }^{7}$ The difference between a control and a proneness variable is that the latter does not account for correlations of the treatment variables. The goal of proneness variables is to construct a plausible counterfactual outcome distribution, without the influence of the treatment.
} 
threshold relates to the additional amount of household income, since not only the lower but also the upper contribution threshold is exceeded.

We estimate QTE models using 500 Monte-Carlo-Markov-Chain draws with a burn-in of 200 draws. ${ }^{8}$ We present the average coefficient across the 300 draws net of the burn-in, as well as $95 \%$ confidence intervals for the average coefficient.

\subsubsection{Decomposition of $U Q R$}

Our second goal is to estimate the contribution of households with at least one member earning above a respective threshold to income dispersion within the upper quarter of the distribution over time. We estimate UQR using recentered influence functions for each time point and for each percentile from the $75^{\text {th }}$ to the $96^{\text {th }}$ percentile of the income distribution to identify the influence of each household type on the respective quantile value (Firpo, Fortin, and Lemieux 2009). Subsequently, we apply a twofold Kitagawa-Oaxaca-Blinder-Decomposition using 1993/94 as the reference time point. This yields composition effects, on the one hand, and income structure effects, on the other (Fortin, Lemieux, and Firpo 2011). The first quantity answers the question whether a change in the share of households with at least one member with payroll-free labor income within the entire population changes a specific unconditional quantile value over time. If the overall share increases over time, we expect an increase in the upper quantile values. If it declines, we accordingly expect a reduction in the quantile values. The second effect answers the question to what extent changes in the probability of households earning beyond a specific unconditional quantile change the unconditional quantile value over time. If all else is held equal, but households with payroll tax-free labor income become more likely to form part of the upper $5 \%$, the $95^{\text {th }}$ percentile value must increase, because it is the separator for the upper $5 \%$ of all units. If the likelihood of such households forming part of the upper 5\% increases and all else is equal, there must be a higher number of them in the upper $5 \%$, which impacts the value of the $95^{\text {th }}$ percentile as separator to the upper $5 \%$. The strength of the influence on the percentile values depends on the sample share of these households. In regard to changing unconditional quantiles, it is important whether a tiny group or a large group is selected more strongly into the top over time.

Figure 1 exemplifies both distributional effects using simulated data for two time points. At $\mathrm{t}_{1}$, the group represents $10 \%$ of all households and is overrepresented in the upper income

\footnotetext{
${ }^{8}$ Monte-Carlo-Markov-Chain estimators need a burn-in phase in which they search for the best solution. Later on, they oscillate around this best solution. We thus use only the latest 300 draws, because the results of the earlier ones do not refer to the most plausible coefficient.
} 
distribution. We hold everything else equal at $t_{2}$, except for the share of the group, which is now $30 \%$. The change in the group's share changes the shape of the distribution's upper half and increases the $95^{\text {th }}$ percentile value by 0.66 points. The growth of a group changes the composition of all groups in the data, and thus the shape of the distribution, resulting in percentile value changes.

Composition effects need to be distinguished from income structure effects. A group may not only change its share but also the shape of its group-specific income distribution, exemplified in the lower panel of Figure 1 . The simulation starts with the same $t_{1}$ setting as previously. For $\mathrm{t}_{2}$, we do not change the group's proportion but the dispersion of income within the group. Again, this group-specific change disperses the upper tail of the unconditional distribution and increases the $95^{\text {th }}$ percentile value by 0.61 points. ${ }^{9}$

a) Change of the share (Composition effect)

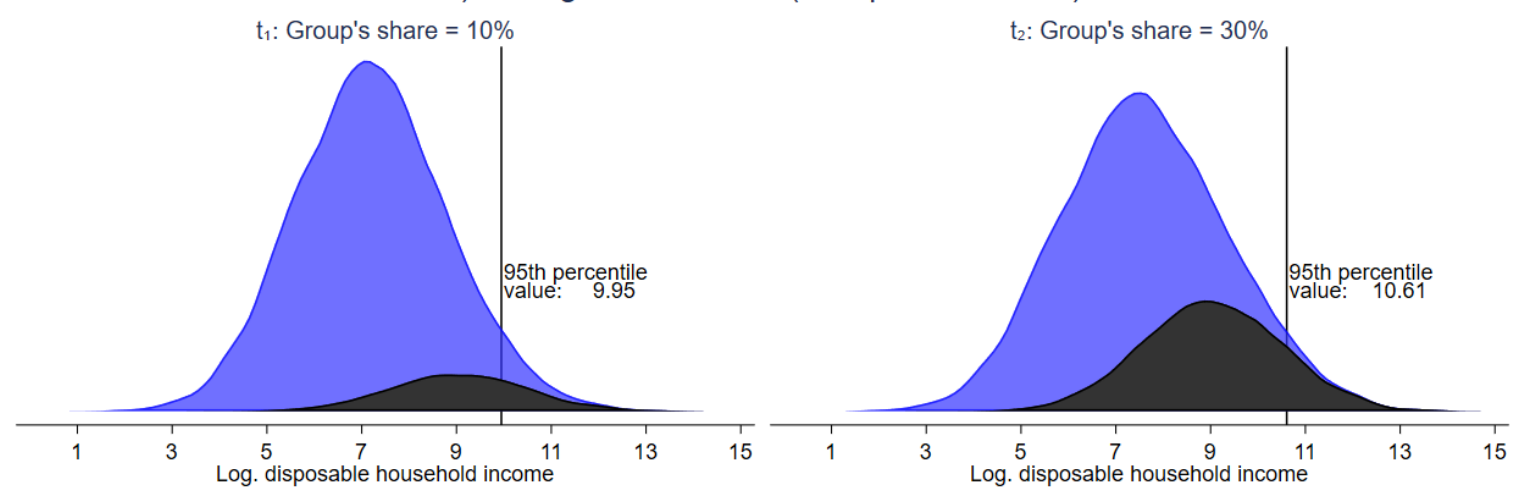

b) Change of the distributional shape (Income structure effect)

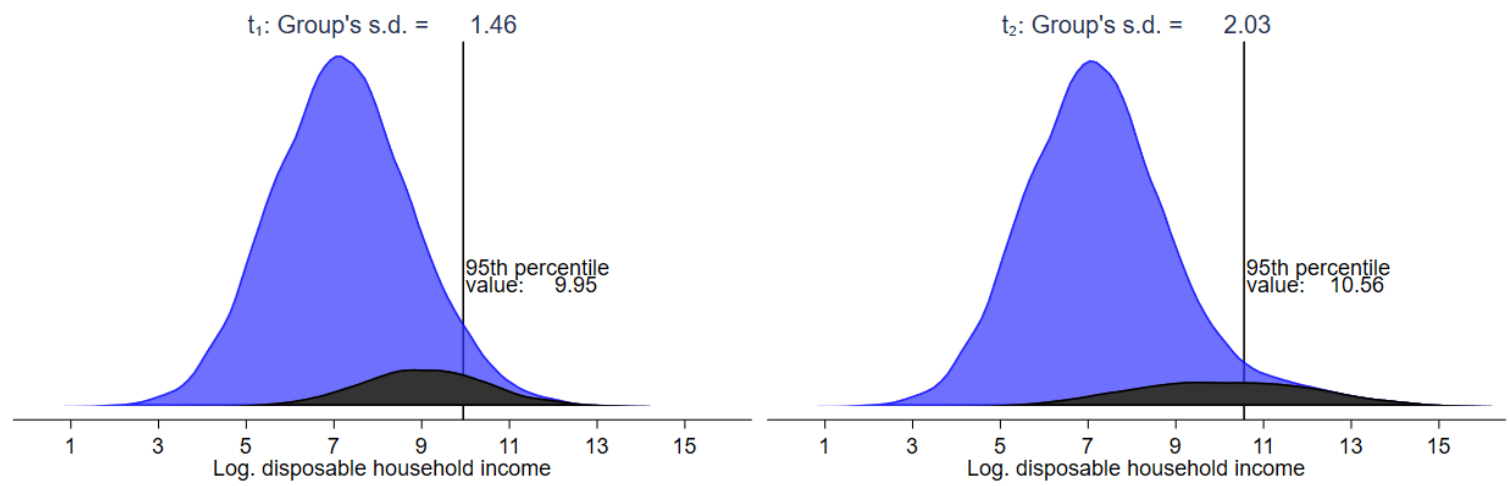

Figure 1: Consequences of changes in a group's share (upper panel) and the group-specific income distribution for the shape of the overall distribution and the unconditional $95^{\text {th }}$ percentile value. Note: The group's distribution (black) is rescaled such that it shows the share of the group within the sample. The y-axis (not shown) for the graphs thus refers not to the density but to the rescaled density for all distributions. The graphs are based on simulated data using 20,000 cases each.

\footnotetext{
${ }^{9}$ Unobserved heterogeneity is part of the income structure effects in a decomposition, especially regarding the constant.
} 


\section{Results}

\subsection{Descriptive results}

Between 1992/93 and 2016/17, household incomes dispersed within the upper quarter of the distribution. Figure 2 plots the change of the $80^{\text {th }}, 85^{\text {th }}, 90^{\text {th }}$, and $95^{\text {th }}$ percentile values over time. Within the observed time interval, both the $90^{\text {th }}$ and especially the $95^{\text {th }}$ percentile had a steeper growth compared to the $80^{\text {th }}$ and $85^{\text {th }}$ percentile. The $95^{\text {th }}$ grew by $15.6 \%$, while the $80^{\text {th }}$ percentile value grew by $13.4 \%$, which is still a considerable increase, but a smaller one compared to top percentiles, resulting in increased income inequality within the upper quarter.

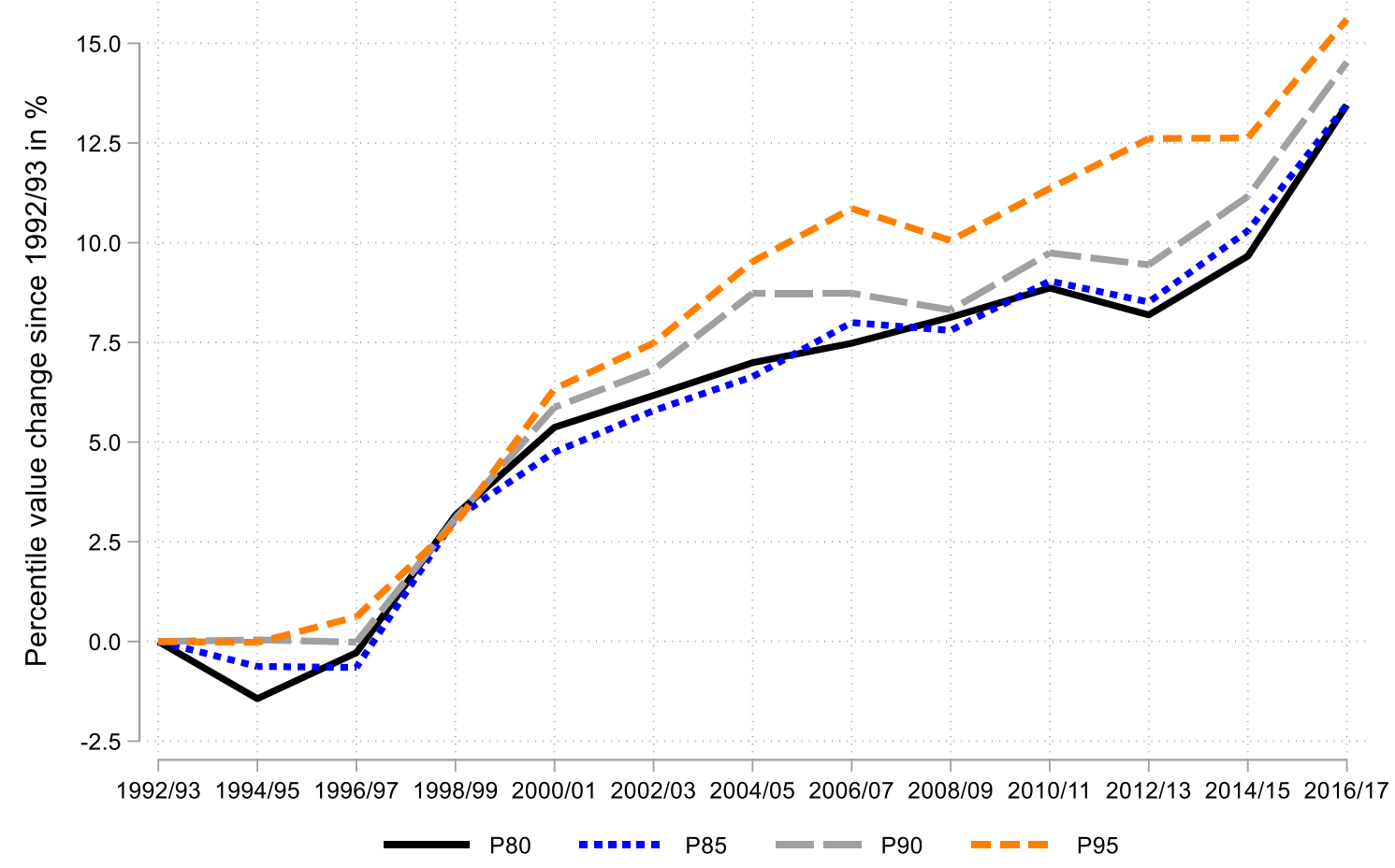

Figure 2: Increasing income dispersion in Germany in the upper quarter of the disposable income distribution, 1992/93-2016/17. Note: See Table A1 in Appendix A for additional information.

Furthermore, four major trends help us to understand this dispersion. First, only labor incomes at the very top - around the $95^{\text {th }}$ percentile and higher - have outpaced the increase in contribution thresholds (Figure 3a). Second, the share of payroll-exempted labor income has increased steadily over time (Figure $3 \mathrm{~b}$ ). Third, this trend runs counter to a decreasing overall share of households with payroll-exempted labor incomes in the population (Figure 4a). Fourth, households with payroll-exempted income tend to concentrate in the top $10 \%$ over time (Figure $4 \mathrm{~b})$. This indicates that a smaller proportion of households accumulate larger sums of payroll tax-free labor income, resulting in smaller differences between pre-tax and post-tax income at the top. 
Between 1992 and 2017, the distribution of top annual labor incomes dispersed, with steeper growth rates for the top percentiles (Figure 3a). The West German $97^{\text {th }}$ percentile increased by $23.5 \%$, from about $€ 75,800$ in 1992 to $€ 93,600$ in 2017 . In contrast, the $80^{\text {th }}$ percentile grew from $€ 43,600$ to $€ 47,600$ (or $9.3 \%$ ) over the same period (compared to a flat trend for average labor income).

The (deflated) level of both contribution thresholds has changed differently over time. The lower threshold was located slightly above the $80^{\text {th }}$ percentile for West Germany and more or less paralleled it, at $+13.9 \%$, between 1992 and 2017. The upper threshold has increased more strongly, by $+24.7 \%$, with most of the change occurring between 2002 and 2003 . Over the years, the upper threshold has moved between the $92^{\text {th }}$ and $95^{\text {th }}$ percentiles of West German labor incomes.

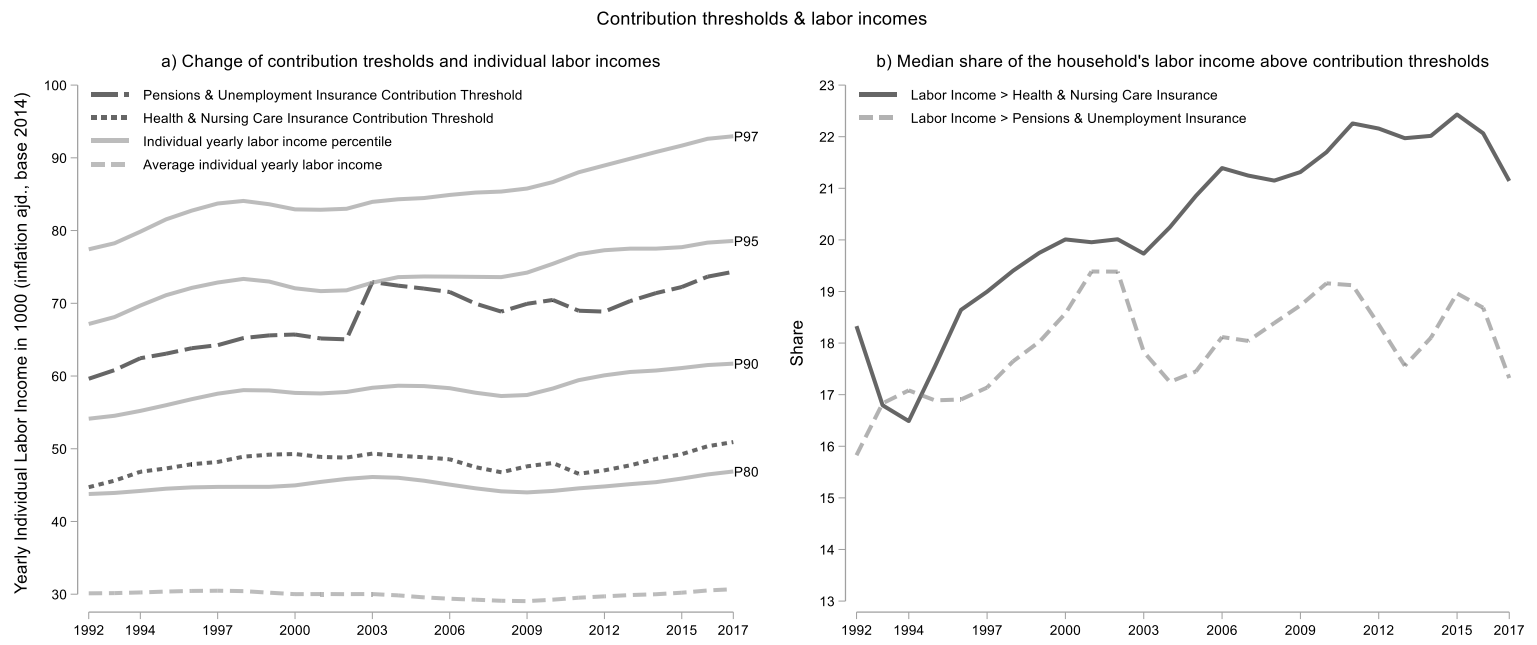

Figure 3: West German social contribution thresholds and percentiles for yearly labor incomes for West German employees (left) and the median share of the household's labor income above the respective contribution threshold for households with labor incomes above the threshold. Both graphs show smoothed trends.

If labor incomes above contribution thresholds grew more strongly than these thresholds, the share of payroll-exempt labor incomes for households would increase over time. Figure $3 \mathrm{~b}$ plots the median share of the payroll-exempt labor income of households with at least $€ 1$ of payrollexempt income. The median share of earned income exempt from health and care contributions rose from $18 \%$ in 1992 to $22.3 \%$ in $2017 .{ }^{10}$ Between 1992 and 2002, the typical share of earned

\footnotetext{
${ }^{10}$ Note that this is equal to the total share of payroll-exempted labor income because this is the lower threshold and thus includes incomes above the upper threshold.
} 
income above the upper threshold rose from $16 \%$ to over $19 \%$. It then decreased to and fluctuated around $17 \%$.

The increasing value of payroll-exempted labor incomes is concentrated in a declining proportion of households whose members earn above these thresholds. The share of these high earner households increased from $15.6 \%$ in 1992 to $16.0 \%$ in 2002, but then dropped to $13.1 \%$ (Figure 4a). The share of households with at least one member earning above the upper threshold increased minimally, from $7.3 \%$ in 1992 to $7.6 \%$ in 2002, and dropped sharply to $5.2 \%$ in 2003 . Since then, it has increased only slightly, to $5.3 \% .^{11}$

However, entire population numbers may neglect the concentration of households with payrollexempted labor incomes at the top of the distribution. Focusing on the upper quarter of the distribution reveals marked increases in their share, especially within the top 10\% (Figure 4b). We calculate a general increase in the share of households with at least one member earning above the lower threshold in the upper quarter. Between the $75^{\text {th }}$ and $79^{\text {th }}$ percentiles, the share increased from $21.8 \%$ to $26.9 \%$ between $1993 / 94$ and 2013/14. For the upper 5\%, the share increased further, from a high level of $64 \%$ in $1993 / 94$ to $71.2 \%$ in $2013 / 14$. Contrary to this trend, the share of households with a member earning above the upper threshold fell between the $75^{\text {th }}$ and $90^{\text {th }}$ percentile due to the sharp increase in the upper threshold between 2002 and 2003. However, despite lifting the upper threshold sharply, the share of households with a member earning above it increased in the upper $10 \%$. Within the range of the $90^{\text {th }}$ to the $94^{\text {th }}$ percentiles, the share of such households dropped only slightly after the increase in 2003 , but has increased since then by 10 percentage points. Within the upper 5\%, the share grew continuously, from $50.2 \%$ in $1993 / 94$ to $62.6 \%$ in $2013 / 14$.

\footnotetext{
${ }^{11}$ A higher share of pensioner households could reduce their share on aggregate, too, because the proportion of households with employed members has declined generally due to population aging. However, the trend remains similar if we exclude pensioner households (see Figure A1 in the Appendix).
} 


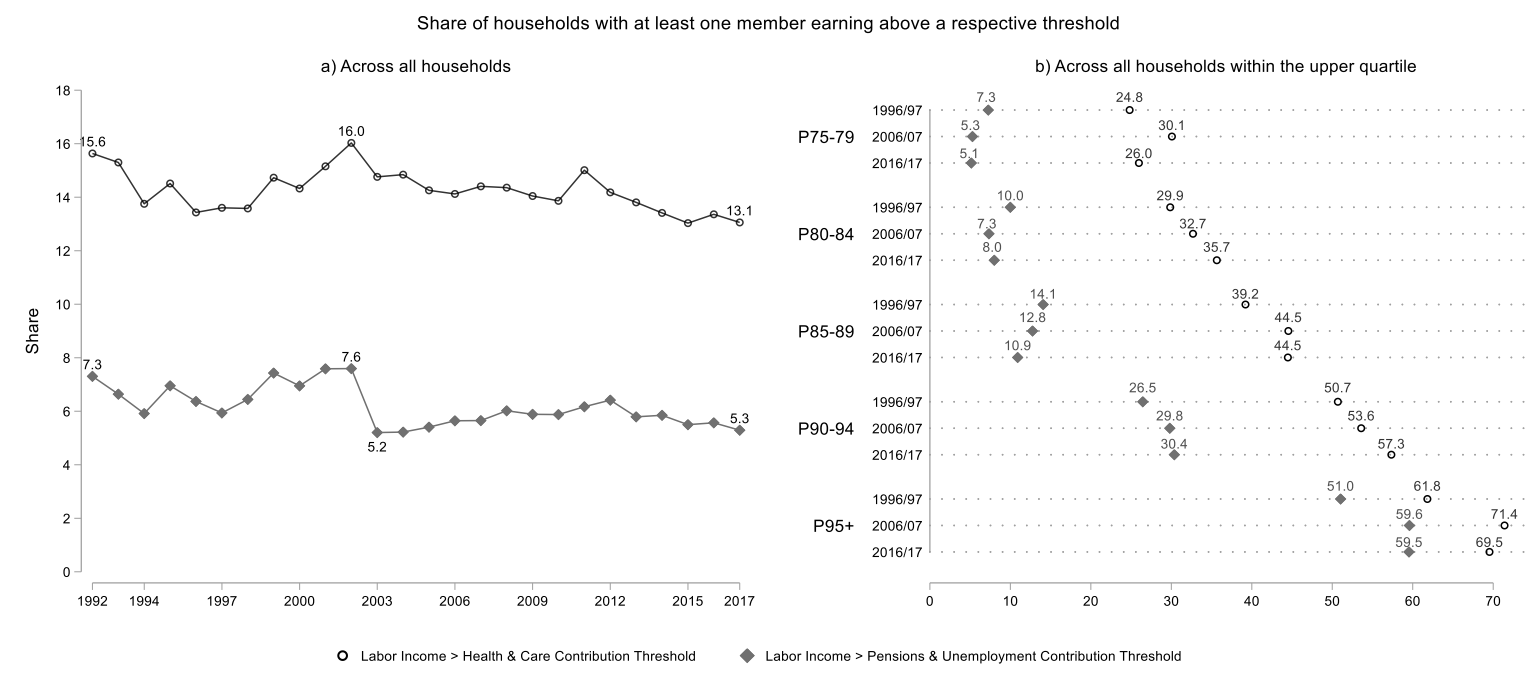

Figure 4: Share of households with at least one member earning above a respective threshold relative to all households with labor incomes (left) and with their share within the upper $25 \%$ of the household income distribution (right).

In sum, the results clearly show a concentration of possible income gains for a smaller group of households that are increasingly concentrated at the very top of the distribution. In the next step, we assess how large these gains are, whether they increase over time, and how they influence income inequality.

\subsection{Multivariate results}

\subsubsection{The effect of payroll-exempted labor income on household incomes}

The results of the QTE models show that earning above the contribution thresholds represents a considerable household income benefit - a relative advantage that has grown over time. Given the same amount of labor and capital income, having a member with earnings above the lower threshold leads to a large benefit between the $75^{\text {th }}$ and $80^{\text {th }}$ percentiles, with about $16 \%-18 \%$ of additional disposable household income in 1992/93 (Figure 5).

In 1992/93, exempted incomes above the upper contribution threshold resulted in an additional disposable income of $6.8 \%$ for households which, based on their characteristics, we would expect to be in the $75^{\text {th }}$ percentile. This advantage has increased strongly across the upper quarter. The relative benefit of earning above each threshold has increased over time. The treatment effect for the lower threshold in the $90^{\text {th }}$ percentile increased from 5.3\% in 1992/93 to $12.1 \%$ in $2004 / 05$, and to $21.2 \%$ in $2017 / 18$. If a household in the $90^{\text {th }}$ percentile has earnings above the upper threshold, we estimate a 20\% higher disposable household income in 1992/93 
compared to a household without such earnings. This effect increased to $27.4 \%$ in 2004/04 and further to $32.7 \%$ in $2016 / 17$.

The results for households earning only above the lower threshold shows a decreasing advantage across the upper quarter. This is a considerable and growing advantage around the $75^{\text {th }}$ percentile - a region of the income distribution where above-average labor incomes are prevalent, but labor incomes above the contribution thresholds are untypical (see Figure $4 \mathrm{~b}$ ). Households with payroll-exempted incomes have a large relative income advantage here. This declines across the distribution as more and more households both share this characteristic and have labor incomes above the upper threshold. Having a member who earns only above the lower threshold thus turns into a negative household characteristic in the top $10 \%$ - at least until the mid-2000s.

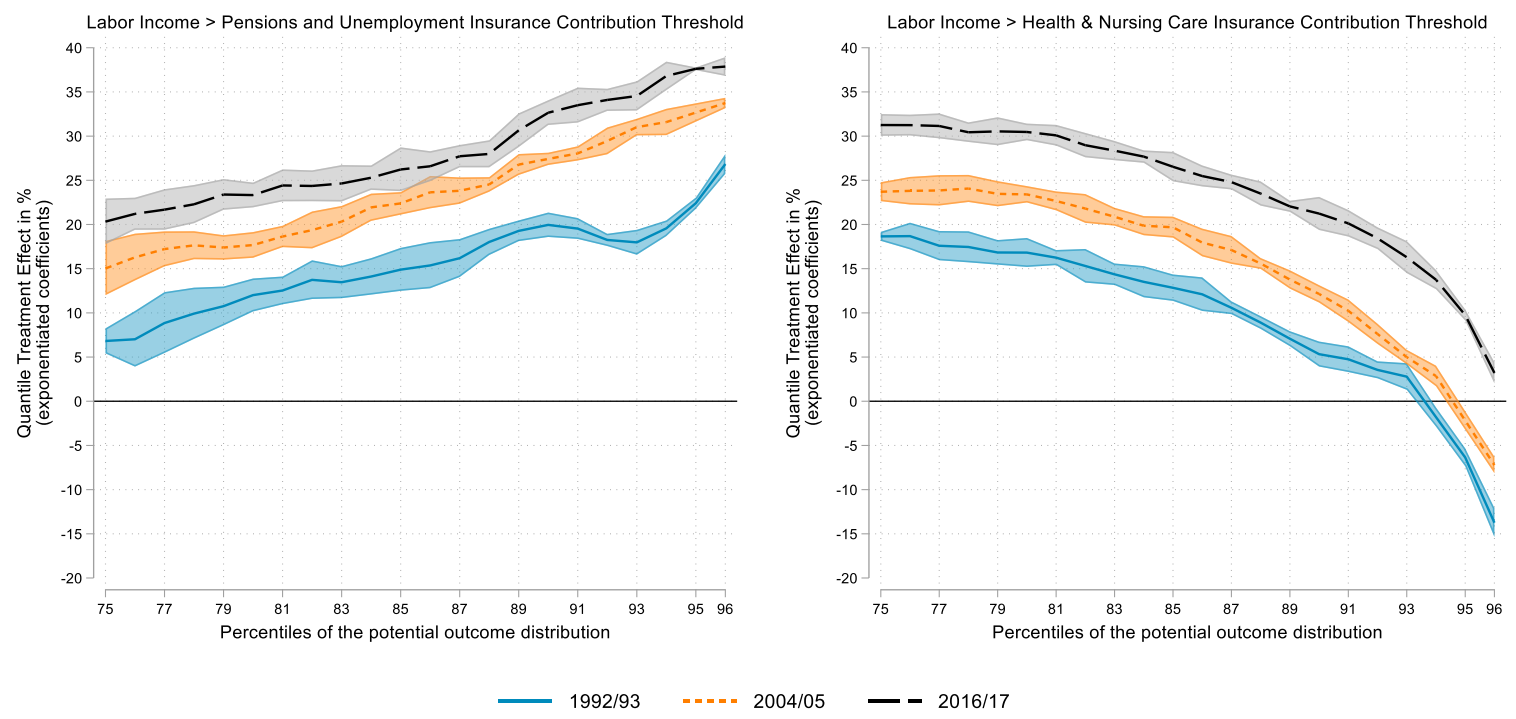

Figure 5: The effect of having at least one member of the household with a labor income above a respective threshold. Note: The graphs show the results of 500 Monte-Carlo-MarkovChain draws per percentile, with the average result over all draws and $95 \%$ confidence intervals based on the parameter variance across draws.

The results support hypotheses H1a and b. There is a substantial benefit from payroll-exempted labor incomes for households in the upper part of the distribution. They also confirm our prediction that this benefit has increased over time $(\mathrm{H} 2)$. We assume that this is a result of strong labor income increases of top-earning household members, leading to larger amounts of payroll tax-exempted income, and thus higher household incomes over time, than we would expect without contribution thresholds. 


\subsubsection{Consequences for income inequality in the upper quarter}

Our second question concerns the role of households with payroll-exempted labor incomes in income inequality in the upper quarter of the distribution over time. To that aim, Figure 6 plots the results of decompositions of UQR. The estimates show three main points.

First, payroll tax-free labor incomes did indeed push households strongly into the upper rungs of the income distribution, leading to increased income dispersion (H3a). Figure $6 \mathrm{~b}$ depicts the income structure effect of households with at least one member earning above both thresholds as a contributor to increased inequality. Between 1992/93 and 2016/17, increases in households' shares of payroll-exempted labor income increased the $85^{\text {th }}$ percentile's value by $1.4 \%$, the $90^{\text {th }}$ 's by $3.6 \%$, and the $95^{\text {th }}$ 's by $6.5 \%$. We estimate a steady increase over time (Figure $\mathrm{C} 1$ in the Appendix), which indicates that continuously increased top-labor incomes (but not changes in payroll tax rates) are responsible for this trend. We conclude that households with at least one member above both thresholds were a main driver of income dispersion at the top of the German income distribution - even after the strong increase in the upper threshold. Top-labor incomes have increased much more than the strong, single increase in the upper threshold. Furthermore, this increase did not significantly affect the large benefit due to payroll taxexempted incomes for these top-income households.

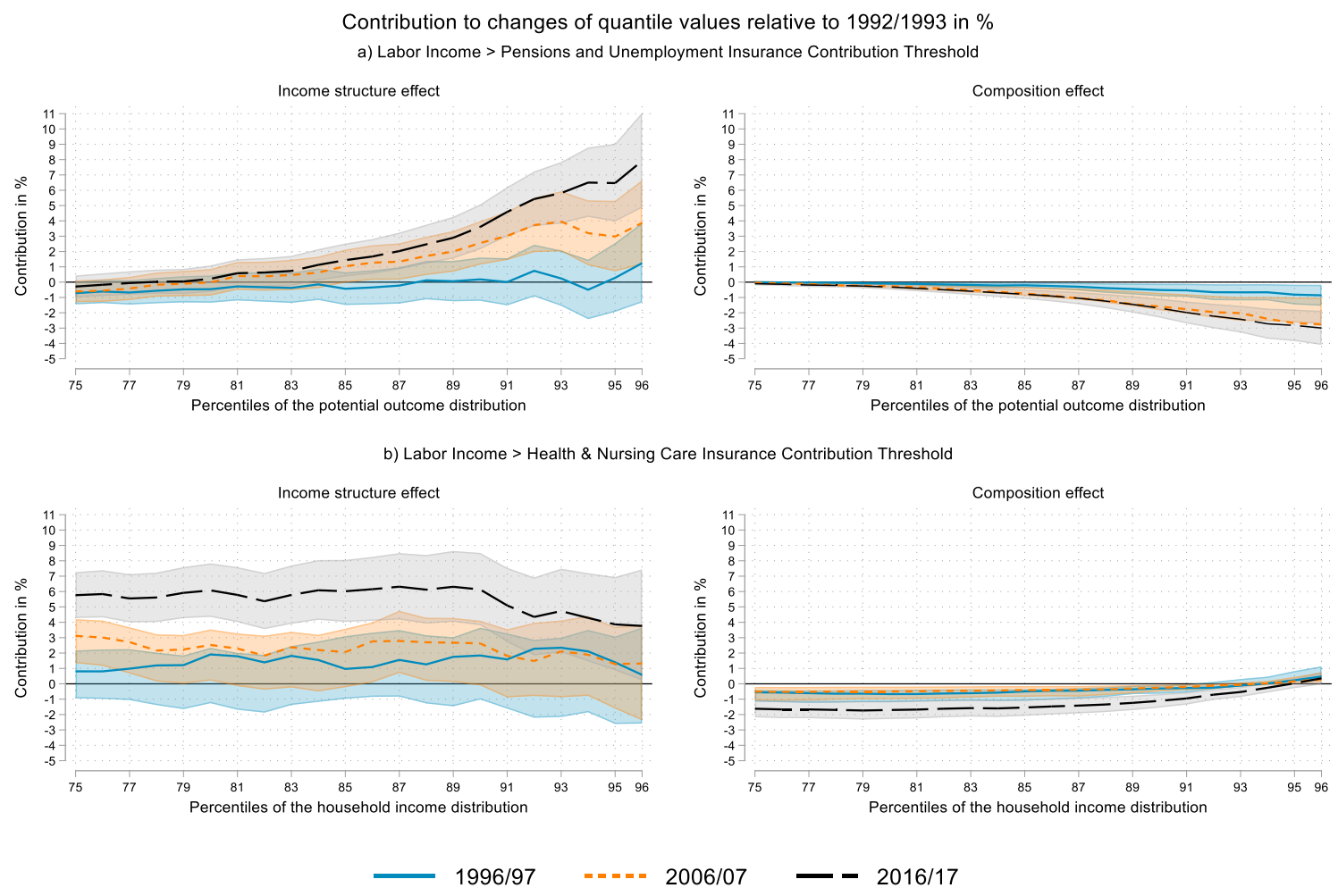

Figures 6a and 6b: The contribution of households with at least one member earning above a contribution threshold for unconditional quantile values relative to 1993/94. 
Second, the reduction in the share of households with a member earning above a respective threshold would have reduced quantile values throughout the upper quarter since 1992/93 only marginally $(\mathrm{H} 3 \mathrm{~b})$. If only the share in households with members earning above the lower threshold changed over time, we would expect a reduction in percentile values between the $75^{\text {th }}$ and $90^{\text {th }}$ percentiles by about $1.7 \%$ between 1993/94 and 2017/18 (Figure 6a, composition effect). We do not find moderate contributions of changed shares above the $92^{\text {nd }}$ percentile. However, we do so for the reduction in shares in households with payroll-exempt labor income above the upper threshold. Here, compositional changes alone would have reduced the upper percentiles by about 3\% between 1993/94 and 2017/18. Most of this reduction is due to the increase in the upper threshold since 2003 (see also Figure C1 in the Appendix).

Third, the income structure effect alone for households with labor incomes above the lower threshold is almost constant across the upper quarter for all time points (Figure 6a, income structure). Furthermore, it increased to 5\%-6\% between 1992/93 and 2016/17. In sum, we do not observe significant differences in contributions on quantile values within the upper quarter; therefore, we conclude that increased shares of labor income exempt from health and nursing care insurance did not drive income inequality within the upper quarter of the German income distribution. Rather, households with labor incomes above both contribution thresholds drove inequality substantially. Nevertheless, labor incomes exempted from the lower health and nursing care insurance contributions increased quantile values across the upper quarter, thereby shifting the upper parts away from the middle.

Overall, increased amounts of payroll-exempted labor income explain large parts of income dispersion in the upper quarter $(\mathrm{H} 3 \mathrm{a})$. For the $75^{\text {th }}$ to the $90^{\text {th }}$ percentiles, labor income, exempted only from the lower contribution threshold, explains about $40 \%$ of the overall change in quantile values between 1992/93 and 2016/17 (Figure 7). Within the upper 10\%, the explanatory power of larger payroll tax amounts decreases to $20 \%$. On top of that, increased labor incomes above both thresholds explains up to $40 \%$ of the change within the upper rungs. As discussed above, this effect increases strongly across the distribution. Thus, its explanatory power is negligible for changes around the $75^{\text {th }}$ percentile. Taken together, however, both effects explain about $60 \%$ of the overall change in upper quantiles between both time points. These results strengthen our view that payroll tax-exempted labor income is a major driver of upper income dispersion. 
Explanatory strength of the income structure effect on quantile value changes 2016/17 - 1992/93

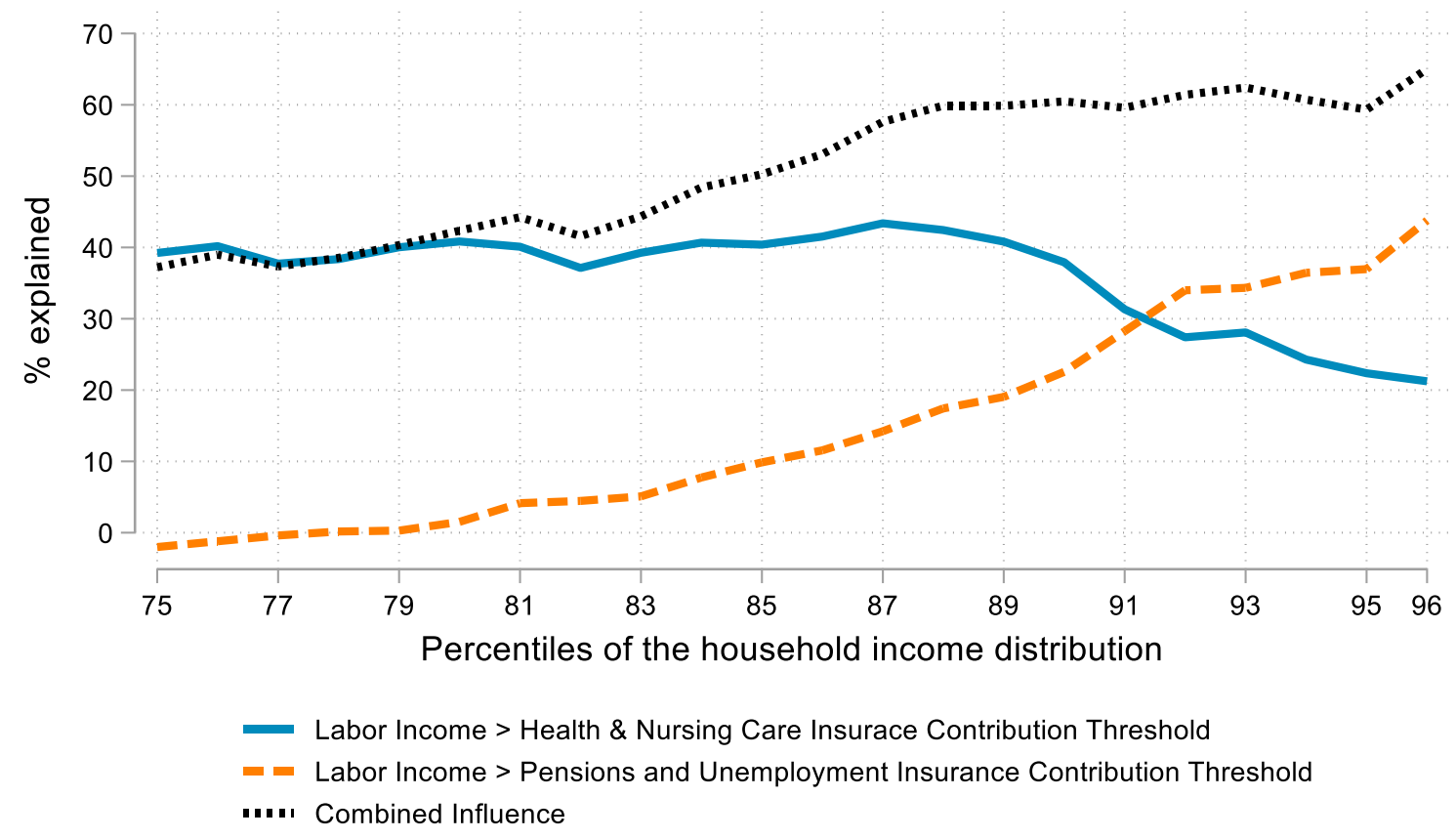

Figure 7: The explanatory power of the income structure effects for income dispersion within the upper quarter between 1992/93 and 2016/17.

\section{Discussion}

Rising economic inequality is a global phenomenon that typically leads to an increase in income dispersion in the upper part of the distribution (Blundell et al. 2018). Here we asked whether a country's payroll tax system might unintentionally reinforce higher income dispersion for the upper part of the distribution by exempting parts of labor income. We showed that for Germany, this is the case because governments did not adjust contribution thresholds in accordance with increased labor income inequality at the top.

Labor incomes above contribution thresholds constitute a significant part of the household's disposable income for a sizable share of German households. Over time, the relative frequency of such households has declined because the federal government has significantly increased the contribution thresholds. However, this has not reduced the typical amount of payroll tax-free labor income, as these households have increased their labor income by more than the government has raised the thresholds. The benefit of payroll tax-free labor incomes became more exclusive after a sharp rise in the contribution thresholds in 2003 , which reduced the proportion of households with at least one member above the upper threshold to around 5\%. More importantly, these households are increasingly concentrated within the top $10 \%$ of the 
income distribution. We show that their payroll tax-free labor income is a major source of income dispersion in the upper tail of the German household income distribution.

Our results confirm our hypothesis that a country's payroll tax system may unintentionally reinforce inequality if exemptions of labor incomes are not caught up by political decisions on thresholds. Despite huge rallies in top-labor incomes, many countries continue to increase payroll tax-caps with average labor incomes as a base, therefore creating a growing post-tax income advantage for high-earners. Although Germany is a highly redistributive country, with comparatively high payroll taxes, large parts of top earnings have flowed out of these institutions that are actually designed to promote solidarity and social cohesion. Our goal is to sensitize researchers focusing on inequality to this largely overlooked mechanism, one which clearly deserves attention.

Our findings complement previous research on rising inequality. Increased college premiums, income gains for analytical tasks, and industry and occupational rents have strongly increased labor incomes. If the country's payroll tax system exempts parts of these gains, top earners receive a twofold advantage which increases overall inequality. Our point here is that these well-studied sources of labor income inequality take place within a country's institutional structure, which can reduce or even reinforce these trends. Here, we have studied the latter case. The partial exemption of labor incomes from payroll taxation increases inequality at the top.

Future research on income inequality can benefit from analyzing the impact of different and possibly changing payroll tax systems on income dispersion. For example, the US has a system of contribution thresholds that is quite similar to the German one. The US has a contributory threshold for the OASDI component of the payroll tax but not for Medicare. Whereas the Medicare tax rate, which applies to all wages, is $2.9 \%$, the OASDI rate is much higher, at $12.4 \%$. Accumulation of labor incomes above contribution thresholds could help clarify income inequality trends. As in the German case, the contribution threshold is adjusted annually according to average wages increases. Therefore, a similar dynamic could be at work in the US, where an increasing portion of labor incomes is exempted from the OASDI payroll tax cap. Thus, we believe that such similarities between tax systems make our analysis particularly instructive for the US case, where discussions about removing the contribution cap are ongoing (Whitman 2009; McGovern 2013). Hence, the architecture of wage taxation combined with wage dispersion could play an important role in the dispersion of household income in the US. 
Differences in payroll tax systems could help us understand differences in income inequality between countries. For example, Norway sets regional social security contributions at between $0 \%$ and $14 \%$ without income thresholds. Switzerland has a nationally uniform social security contribution rate without income thresholds (this is not, however, applied to health insurance). So far, we do not know how such transnational differences in the institutional architecture of payroll taxation affect income inequality for these countries and how this could help us understand inequality trends across countries. We are confident that further studies using the framework presented here will improve our understanding of such cross-country differences and deepen our understanding of the various causes of income inequality.

Our results are strongly relevant for discussions about the accumulation of wealth and increasing segregation. A growing amount of payroll tax-free labor income will most likely find its way into higher household capital formation, in terms of assets and homeownership, thereby translating growing labor income inequality into other dimensions of inequality which need to be studied in more detail. 


\section{References}

Albers, Thilo N. H., Charlotte Bartels, and Moritz Schularick. 2020. "The Distribution of Wealth in Germany, 1895-2018.” ECONtribute Working Paper.

Angeles, Renira C., and Achim Kemmerling. 2020. "How Redistributive Institutions Affect Pay Inequality and Heterogeneity Among Top Managers.” Socio-Economic Review 18 (1): 3-30. doi:10.1093/ser/mwz048.

Bach, Stefan, Giacomo Corneo, and Viktor Steiner. 2013. "Effective Taxation of Top Incomes in Germany." German Economic Review 14 (2): 115-37.

Bach, Stefan, Johannes Geyer, Peter Haan, and Katharina Wrohlich. 2011. "Reform of Income Splitting for Married Couples: Only Individual Taxation Significantly Increases Working Incentives." DIW Economic Bulletin 1 (5): 13-19.

Bartels, Charlotte, and Katharina Jenderny. 2015. "The Role of Capital Income for Top Incomes Shares in Germany.” WTID Working Paper 2015/1.

Bawa, Siraj G., and Nam T. Vu. 2020. "International Effects of Corporate Tax Cuts on Income Distribution.” Int. J. Dev. Neurosci. 28 (5): 1164-90. doi:10.1111/roie.12485.

Biewen, Martin, Martin Ungerer, and Max Löffler. 2019. "Why Did Income Inequality in Germany Not Increase Further After 2005?” German Economic Review 20 (4): 471-504. doi:10.1111/geer.12153.

Bloch, Debbie, Mauro Pisu, and Isabelle Joumard. 2013. "Tackling Income Inequality.” OECD Journal: Economic Studies 2012 (1): 37-70. doi:10.1787/eco_studies-2012$5 \mathrm{k} 95 \mathrm{xd} 61651 \mathrm{t}$.

Blundell, Richard, Robert Joyce, Agnes Norris Keiller, and James P. Ziliak. 2018. "Income Inequality and the Labour Market in Britain and the US." Journal of Public Economics 162:48-62. doi:10.1016/j.jpubeco.2018.04.001.

Borgen, Nicolai T., Andreas Haupt, and Øyvind N. Wiborg. 2020. Quantile Regression Models and the Crucial Difference Between Individual-Level Effects and Population-Level Effects. SocArXiv.

Brady, David, and Amie Bostic. 2015. "Paradoxes of Social Policy." American Sociological Review 80 (2): 268-98. doi:10.1177/0003122415573049. 
Duncan, Denvil, and Klara S. Peter. 2016. "Unequal Inequalities: Do Progressive Taxes Reduce Income Inequality?" International Tax and Public Finance 23 (4): 762-83. doi:10.1007/s10797-016-9412-5.

Dustmann, Christian, Bernd Fitzenberger, and Markus Zimmermann. 2018. "Housing Expenditures and Income Inequality." ZEW-Centre for European Economic Research Discussion Paper (18-048).

Dustmann, Christian, Johannes Ludsteck, and Uta Schönberg. 2009. "Revisiting the German Wage Structure.” The Quarterly Journal of Economics 124 (2): 843-81.

Firpo, Sergio, Nicole M. Fortin, and Thomas Lemieux. 2009. "Unconditional Quantile Regressions.” Econometrica 77 (3): 953-73. Accessed February 13, 2015.

Fortin, Nicole M., Thomas Lemieux, and Sergio Firpo. 2011. "Decomposition Method in Economics." In Handbook of Labor Economics, edited by Orley Ashenfelter and David Card. 1st ed., 1-102. Handbooks in Economics 4a. Amsterdam: North-Holland.

Godechot, Olivier. 2016. Wages, Bonuses and Appropriation of Profit in the Financial Industry: The Working Rich. Routledge.

Goebel, Jan, Markus M. Grabka, Stefan Liebig, Martin Kroh, David Richter, Carsten Schröder, and Jürgen Schupp. 2019. "The German Socio-Economic Panel (SOEP).” Jahrbücher für Nationalökonomie und Statistik 239 (2): 345-60. doi:10.1515/jbnst-20180022.

Goodhart, Charles A. E., and Manoj Pradhan. 2020. The Great Demographic Reversal: Ageing Societies, Waning Inequality, and an Inflation Revival. Cham: Springer International Publishing.

Gornick, Janet C., and Timothy M. Smeeding. 2018. "Redistributional Policy in Rich Countries: Institutions and Impacts in Nonelderly Households." Annual Review of Sociology (44): 441-68.

Grabka, Markus M., and Jan Goebel. 2020. “Real Incomes Increasing, Low-Income Rate Decreasing in Individual Age Groups.” DIW Weekly Report 10 (17/18): 231-39.

Immervoll, Herwig, and Linda Richardson. 2011. "Redistribution Policy and Inequality Reduction in OECD Countries." OECD Social, Employment and Migration Working Papers, no. 122. doi:10.1787/5kg5dlkhjq0x-en. 
Kaplan, Steven N., and Joshua Rauh. 2013. "It's the Market: The Broad-Based Rise in the Return to Top Talent.” The Journal of Economic Perspectives 27 (3): 35-55.

Lakner, Christoph, and Branko Milanovic. 2016. "Global Income Distribution: From the Fall of the Berlin Wall to the Great Recession.” The World Bank Economic Review 30 (2): 20332. doi:10.1093/wber/lhv039.

Liu, Yujia, and David B. Grusky. 2013. "The Payoff to Skill in the Third Industrial Revolution.” Am J Sociol 118 (5): 1330-74. doi:10.1086/669498.

Martin, Isaac W., Ajay K. Mehrotra, and Monica Prasad, eds. 2009. The New Fiscal Sociology: Taxation in Comparative and Historical Perspective. Cambridge University Press.

Martin, Isaac W., and Monica Prasad. 2014. "Taxes and Fiscal Sociology.” Annual Review of Sociology 40 (1): 331-45.

Marx, Ive, Lina Salanauskaite, and Gerlinde Verbist. 2016. "For the Poor, but Not Only the Poor: On Optimal Pro-Poorness in Redistributive Policies.” Social Forces 95 (1): 1-24. doi:10.1093/sf/sow058.

McCaffery, Edward J. 2007. Taxing Women. University of Chicago Press.

McCall, Leslie, and Christine Percheski. 2010. "Income Inequality: New Trends and Research Directions.” Annual Review of Sociology 36: 329-47.

McGovern, Kate. 2013. "Lessons from the Snowy Slope: Vision and Politics in American Social Insurance.” American Journal of Economics and Sociology 72 (1): 59-89. doi:10.1111/j.1536-7150.2012.00868.x.

Meier, V., and M. Werding. 2010. "Ageing and the Welfare State: Securing Sustainability." Oxford Review of Economic Policy 26 (4): 655-73. doi:10.1093/oxrep/grq031.

Nolan, Brian, Matteo G. Richiardi, and Luis Valenzuela. 2019. “The Drivers of Income Inequality in Rich Countries.” Journal of Economic Surveys 33 (4): 1285-1324. doi:10.1111/joes.12328.

O’Brien, Rourke L. 2017. "Redistribution and the New Fiscal Sociology: Race and the Progressivity of State and Local Taxes.” American Journal of Sociology 122 (4): 1015-49. doi:10.1086/690118.

OECD. 2011. "Divided We Stand: Why Inequality Keeps Rising." OECD Publishing. 
Piketty, Thomas, and Emmanuel Saez. 2003. "Income Inequality in the United States, 19131998." The Quarterly Journal of Economics 118 (1): 1-41. doi:10.1162/00335530360535135.

Piketty, Thomas, Emmanuel Saez, and Gabriel Zucman. 2018. "Distributional National Accounts: Methods and Estimates for the United States.” The Quarterly Journal of Economics 133 (2): 553-609. doi:10.1093/qje/qjx043.

Powell, David. 2020. "Quantile Treatment Effects in the Presence of Covariates.” Review of Economics and Statistics 102 (5): 994-1005.

Schechtl, Manuel. 2021. "The Taxation of Families: How Gendered (De)Familialization Tax Policies Modify Horizontal Income Inequality.” Journal of Social Policy 1-22. doi:10.1017/S0047279421000404.

Scheve, Kenneth, and David Stasavage. 2016. Taxing the Rich: A History of Fiscal Fairness in the United States and Europe. Princeton University Press.

Stainback, Kevin, Donald Tomaskovic-Devey, and Sheryl Skaggs. 2010. “Organizational Approaches to Inequality: Inertia, Relative Power, and Environments.” Annual Review of Sociology 36 (1): 225-47. doi:10.1146/annurev-soc-070308-120014.

Volscho, Thomas W., and Nathan J. Kelly. 2012. "The Rise of the Super-Rich Power Resources, Taxes, Financial Markets, and the Dynamics of the Top 1 Percent, 1949 to 2008." American Sociological Review 77 (5): 679-99.

Wagner, Gert G., Joachim R. Frick, and Jürgen Schupp. 2007. "The German Socio-Economic Panel Study (SOEP) - Scope, Evolution and Enhancements.” Schmollers Jahrbuch 127 (1): 139-69.

Wang, Chen, Koen Caminada, and Kees Goudswaard. 2014. "Income Redistribution in 20 Countries over Time.” International Journal of Social Welfare 23 (3): 262-75. doi:10.1111/ijsw.12061.

Whitman, Kevin. 2009. "Distributional Effects of Raising the Social Security Taxable Maximum.” Policy Brief (2009-01).

Wimer, Christopher, Zachary Parolin, Anny Fenton, Liana Fox, and Christopher Jencks. 2020. "The Direct Effect of Taxes and Transfers on Changes in the U.S. Income Distribution, 1967-2015." Demography 57: 1833-51. doi:10.1007/s13524-020-00903-6. 